\title{
The rate of tobacco smoking among dental school students in Turkey
}

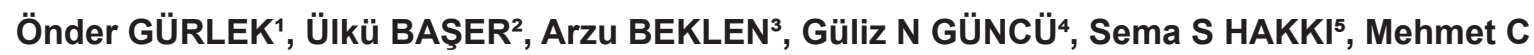 \\ HAYTAÇ ${ }^{6}$, Leyla KURU ${ }^{7}$, Müge LÜTFIOĞLU ${ }^{8}$, Pınar MERiçÇ ${ }^{1}$, Ebru OLGUN ${ }^{9}$, Burcu ÖZDEMIR ${ }^{10}$, \\ Zekeriya TAŞDEMIR ${ }^{11}$, Nurcan BUDUNELi ${ }^{1}$ \\ Department of Periodontology, Faculty of Dentistry, \\ ${ }^{1}$ Ege University, İzmir, ${ }^{2} \mid$ Istanbul University, İstanbul, ${ }^{3}$ Osmangazi University, Eskişehir, ${ }^{4}$ Hacettepe University, Ankara, \\ ${ }^{5}$ Selçuk University, Konya, ${ }^{6}$ Çukurova University, Adana, ${ }^{7}$ Marmara University, İstanbul, ${ }^{8}$ On Dokuz Mayıs University, Samsun, \\ ${ }^{9}$ Kırıkkale University, Kırıkkale, ${ }^{10} \mathrm{Gazi}$ University, Ankara, ${ }^{11}$ Erciyes University, Kayseri, Turkey
}

Atıf/Citation: Gürlek, Ö., Başer, Ü., Beklen, A., Güncü, G.N., Hakkı, S.S., Haytaç, M.C., Kuru, L., Lütfioğlu, M., Meriç, P., Olgun,E., Özdemir, B., Taşdemir, Z. \& Buduneli, N. (2019). The rate of tobacco smoking among dental school students in Turkey. Ege Üniversitesi Diş Hekimliği Fakültesi Dergisi, 40(3), 185-191.

\begin{abstract}
Objectives: This survey aimed to investigate the attitudes of the first- and fifth-year Turkish dental school students towards tobacco and to determine the prevalence of those using various tobacco products.

Materials \& Methods: The survey was conducted between May 1 and June 30, 2018 and the first- and fifth-year students were from eleven dental schools located in different regions of Turkey. Data were tested statistically using Statistical Package for Social Science (SPSS) program.

Results: A total of 1228 students participated and 1096 completed the online survey. The majority of the participants were females $(n=691,63.05 \%)$. Mean age of the participants was $21.8 \pm 2.9$ years (age range 18-54 years). Although the overall rate of current smokers was $37.96 \%, 62.04 \%$ of the participants had inhaled tobacco smoke at least once. More than half $(55.19 \%)$ of the current smokers stated that they wish to quit and $29.26 \%$ of these students have attempted to quit within the last six months. Only $19.49 \%$ of all participants defined themselves as highly addicted to cigarette smoking. The rate of waterpipe smokers was $41.2 \%$, of which $83.7 \%$ declared that they had no intention to quit.
\end{abstract}

Conclusion: This study shows that the rate of tobacco smokers is rather high among dental school students in Turkey and this finding points out the need for novel and more effective precautions against tobacco.

Key words: dental student; smoking; survey; tobacco products; waterpipe

ÖZ

Amaç: Bu anket çalışması, Türkiye'de birinci ve beşinci sınıf diş hekimliği öğrencilerinin tütün ürünleri konusundaki tutumlarını araştırmayı ve tütün ürünleri kullananların prevalansını belirlemeyi amaçlamaktadır.

Gereç ve Yöntem: Bu araştırma 1 Mayıs-30 Haziran 2018 tarihleri arasında, birinci ve beşinci sınıfta okuyan öğrencilerle, Türkiye'nin farklı bölglerinde bulunan 11 diş hekimliği fakültesinde eş zamanlı olarak gerçekleştirildi. Anket formlarının istatistiksel analizi aşamasında SPSS 21.0 programından yararlanıldı.

Bulgular: Çalışmaya katılan 1228 öğrencilerden 1096 kişi çevrimiçi anket sorularının tamamını yanıtladı. Katıımcıların

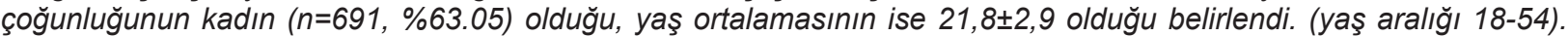
Sigara içenlerin genel oranı \%37,96 olmasına rağmen, katılımcıların \%62,04'ü en az bir kez tütün ürünü denediklerini bildirdiler. Sigara içenlerin yarısından fazlası $(\% 55,19)$ sigarayı bırakmak istediklerini belirtirken, bu öğrencilerin \%29,26'sının son altı ay içinde sigarayı bırakma girişiminde bulundukları tespit edildi. Tüm katılımcıların sadece \%19,49'u kendilerini sigara içmeye oldukça bağımlı olarak tanımladı. Nargile içenlerin oranı \%41,2 idi ve nargile içenlerin \%83,7'si nargileyi bırakmaya niyetlerinin olmadığını bildirdi.

Sonuç: Bu çalışma, Türkiye'de sigara içme oranının diş hekimliği fakültesi öğrencileri arasında oldukça yüksek olduğunu ve tütün karşıtı yeni ve daha etkili önlemlere ihtiyaç duyulduğunu göstermektedir.

Anahtar kelimeler: diş hekimliği öğrencisi; sigara; anket; tütün ürünleri; nargile 


\section{Introduction}

Tobacco continues to be the leading global cause of preventable diseases and death. With the current trend, it is estimated that tobacco products will cause 8 million deaths by year 2030 which will account to $80 \%$ of death among young population living in low- and middleincome countries. ${ }^{1}$ While adult smoking rates in Europe have decreased by $5 \%$ since 2000 , adolescent smoking is reported to be on the rise. ${ }^{2}$ Three groups of factors are known to influence adolescent smoking rates: a) family (parental smoking, number of smokers in the family, parental permissiveness), b) social factors (number of friends who smoke, and expectation by friends) and c) individual characteristics (gender, ethnicity, concerns with body-weight, attitudes to smoking etc.). ${ }^{3}$

A previous study showed that the average age of the first cigarette consumption is 15.4 years and the average age of starting daily consumption of cigarettes is 18 years. ${ }^{4}$ Adolescents starting to smoke at an early age tend to become more addicted to cigarettes and less willing to quit.

Smoking contributes to $40-45 \%$ of all cancer deaths, $90-95 \%$ of lung cancer deaths, over $85 \%$ of oral cancer deaths, $35 \%$ of cardiovascular disease deaths, and $75 \%$ of deaths due to chronic obstructive lung disease in the age group ranging from 35 to 69 years. ${ }^{5}$ Tobacco product consumption has many adverse effects in the oral cavity apart from oral cancers. The major ones are staining of the teeth, deficiencies in smelling and taste, melanosis, and oral candidiasis. ${ }^{6}$ It is well established that smoking increases the prevalence and severity of periodontal diseases and hampers the response to periodontal therapy. ${ }^{7}$

Physicians are often perceived as a role model for their patients and many of them encourage smoker patients to quit smoking. Also dental team has a key role to play helping smoking cessation. Since most of the early signs of tobacco consumption are observed in the oral cavity, this installs dentists a critical role for counselling. Tobacco consumption habits of dental students have been investigated in different countries. ${ }^{1,8,9}$ However, little is known about dental students' tobacco consumption and possible factors affecting their attitudes towards tobacco products in Turkey.

Therefore, the aim of this study was to evaluate the prevalence of tobacco consumption and attitudes of the first- and fifth-year dental students toward tobacco consumption in different dental schools in Turkey.

\section{Materials \& Methods}

\section{Sample selection}

This cross-sectional study was conducted at 11 different dental schools in Turkey. The study was designed as an online self-administered anonymous questionnaire to the first- and fifth-year students. At first, verbal information was given to the students about the study and voluntary participation and anonymity were provided. The study was conducted in full accordance with ethical principles, including the World Medical Association's Declaration of Helsinki, as revised in 2000. The study protocol was approved by the Ethics Committee of Kırıkkale University (Protocol number; 15/38).

\section{Survey methodology}

A completely structured style was used with 40 questions and tick-box answers to encourage students to respond and also to make quantitative statistical analyses possible. Data collection included smoking habits, associated risk factors (parental, social), demographic variables (age, gender, first tobacco consumption, addiction) and willing to quit tobacco consumption. Smoking status was categorized as non-smoker and current smoker.

Students' smoking habits were assessed in terms of first smoking experience, types of smoking (cigarettes, water pipes, e-cigarette), frequency, and quantity. Students were also asked to answer questions about parental education levels, smoking status among parents, siblings, friends, and their intentions to quit in the future.

\section{Statistical analyses}

Data were collected and prepared for statistical analysis with the Statistical Package for the Social Sciences (SPSS) for Windows (version 21, SPSS Inc., Chicago, IL). Assessment of statistical significance between groups was performed using the Pearson ChiSquare test at $\alpha=0.05$. Logistic regression analysis was used to compute the odds ratio (OR) and $95 \%$ confidence interval $(95 \% \mathrm{CI})$, and to determine the effect of different risk factors on smoking habits.

\section{Results}

The questionnaire was sent to 15 different dental schools in Turkey and 11 of them took part in the survey. The list of the partner schools and their participation rates is shown in Figure 1. 


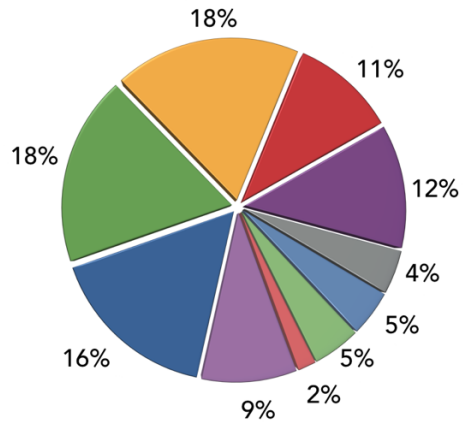

Ege University
Selçuk University
Marmara University
Kirikkale University
Erciyes University
Gazi University
Akdeniz University
Istanbul University
Ankara University
Hacettepe University

Figure 1. The distribution of participants in different university dental schools.

Selçuk and Marmara Universities had the highest participation rates with $18 \%$. In total, 1228 students participated the survey and 1096 of them completed the whole questionnaire, therefore, statistical analysis was performed in these 1096 respondents. The participant dental schools have approximately 3650 students altogether in the first and fifth year. Therefore, the number of responders has the power to represent the whole group. In order to represent the study population with an assumption of margin of error $3 \%$ and confidence interval $95 \%$, minimum sample size was calculated to be 831 . Based on an expected responder rate of $65 \%$, 1228 students were invited to fill the questionnaire.

The age range of the students was 18-54 years with the mean age of $21.8 \pm 2.9$ years. There were 603 students $(55.01 \%)$ in the $1^{\text {st }}$ year and $493(44.99 \%)$ in the $5^{\text {th }}$ year. Most of the participants were female $(n=691,63.04 \%)$. The distribution of the participants by smoking status, gender and year are shown in Table 1.

The distribution according to the tobacco product usage $(+/-)$, first smoking experience (cigarette, waterpipe, e-cigarette) and daily smoking habits (+/-) are shown in Figure 2. A large part of the individuals $(66.70 \%, n=731)$ have tried tobacco products at least once. Two thirds of the students, who tried to inhale cigarette once, continued to smoke later on $(37.95 \%$, $\mathrm{n}=416$ ). The first experience of smoking tobacco was mainly cigarette $(77.02 \%, n=563)$. When the relation between smoking status and gender is evaluated, regardless of the difference in year, non-smoker females were significantly more than the non-smoker males $(p<0.0001)$. The numbers of non-smokers in the fifth year was significantly less than the first-year males $(\mathrm{p}<0.001)$ and females $(\mathrm{p}<0.05)$, respectively. Nonsmoker males were significantly less in the fifth-year group compared to the non-smoker counterparts in the first year $(\mathrm{p}<0.05)$.

\section{Ever used tobacco products}

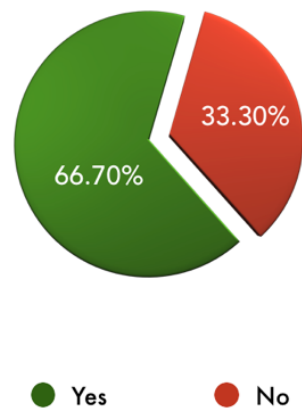

a.

\section{First smoking exprience}

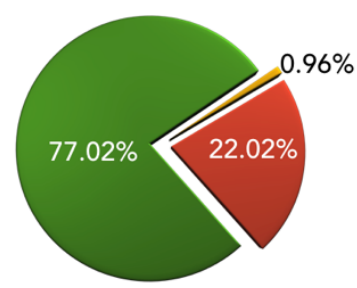

Cigarette Digital Smoke Waterpipe

b.
Daily Smoker

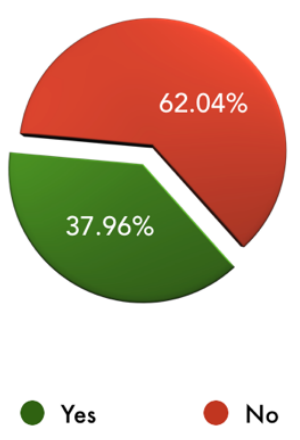

C.

Figure 2. The rates of participants: a. who have ever smoked any tobacco product, b. type of tobacco product for the first inhalation, c. who are daily smokers. 
The social impact of tobacco consumption was evaluated with the questions about friends' smoking habits and parental smoking status. The majority $(64.82 \%)$ of the non-smokers and smokers $(96.57 \%)$ had at least one smoker friend. Being a smoker significantly correlated with having smoker friends $(\mathrm{p}<0.059)$.

In both smoker and non-smoker groups regardless of the year difference, non-smoker parents were significantly more than smoker parents $(\mathrm{p}<0.01)$. Although the number of smoker parents in the smoker group was higher than the non-smoker group, the difference was not statistically significant $(\mathrm{p}>0.05)$ (Figure 3$)$.
Smokers' tobacco addiction was evaluated in three different categories as none, some and high. Most of the smokers think that they are not addicted to tobacco and also claimed that they can quit smoking whenever they want (Figure 4). Smokers were also asked if they wish to quit and their attempts to quit in the last 6 months and the rates were $55.19 \%(\mathrm{n}=298)$ and $29.26 \%(\mathrm{n}=158)$, respectively.

Waterpipe smoking was as common as cigarette smoking. The rate of waterpipe smokers was $36.58 \%$. Only six of the smokers smoked waterpipe every day in the last month, and $83.7 \%$ of waterpipe smokers were not willing to quit.

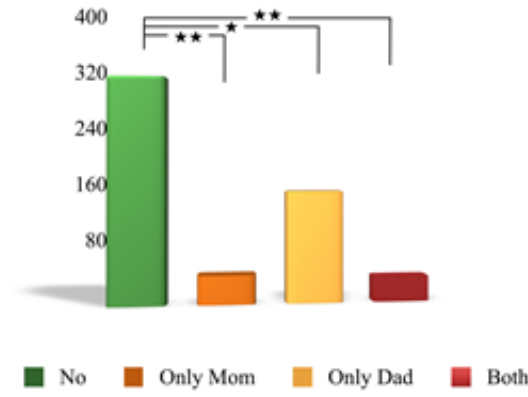

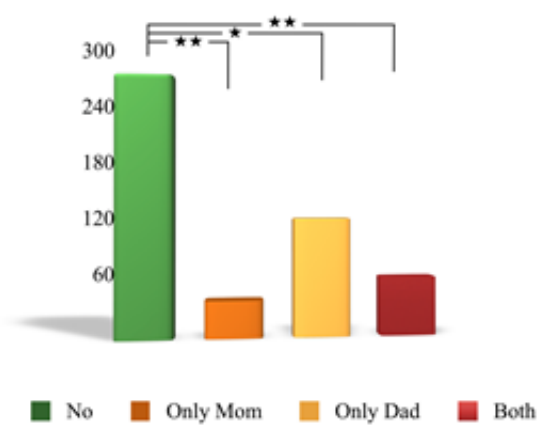

b

Figure 3. a. Parental smoking rates among the non-smoker students. b. Parental smoking rates among the smoker students.

How addicted are you?

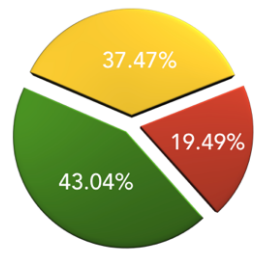

None

Some
Do you want to quit smoking?

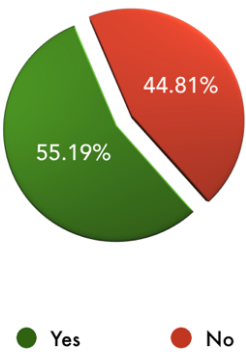

b.
Have you attempted quit
smoking in last 6 months

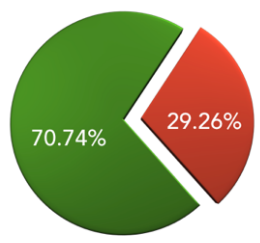

Yes

No

a.

c.

Figure 4. The rates of a. severity of addiction according to the self-reports, b. those willing to quit and those not willing to quit, c. those who have attempted to quit during the last 6 months. 


\section{Discussion}

Despite the clear evidences about the harmful effects of tobacco consumption, many tobacco users even health care providers underestimate the risks to themselves and others. This survey was conducted in 11 different dental schools located in east, west, north, south, and central regions of Turkey. According to the findings, almost 38\% of the 1096 participants were smokers with a higher rate in males.

In a review of smoking rates among medical students in 19 countries, Smith et al. (2007) reported the rates ranged between $3-58 \% .^{10}$ Smoking rates of medical students in Turkey were found to be $22-33 \%$ with males being more likely to be smokers. ${ }^{11,12}$ Smoking rates of males and females were $18-48 \%$ and 5-29\%, respectively, among medical and dental school students in Turkey. ${ }^{14}$ Barber \& Fairclough reported that $7 \%$ of dental students were current smokers, while $9 \%$ were ex-smokers. Tobacco consumption among the fourth-year Iranian dental students was $54.2 \%, 73.0 \%$ of them were males, whereas $44.4 \%$ were females; $50.8 \%$ were smoking waterpipes, $34.2 \%$ cigarettes, and $9.3 \%$ were using other tobacco products. ${ }^{15}$ In the present study, $37.96 \%$ of all participants were smokers. The finding of male smoker preponderance is in line with previous reports. ${ }^{\mathbf{1 0 , 1 4 , 1 5}}$

A previous epidemiological study conducted in a Turkish population over the age of 15 demonstrated that $27 \%$ of individuals were smokers and smoker rates were $13 \%$ and $41 \%$ for females and males, respectively. ${ }^{16} \mathrm{~A}$ recent survey on 2505 university students in Turkey the overall smoking rate was $27.9 \%$, whereas $15.9 \%$ of the females and $46.0 \%$ of the males were smokers. ${ }^{17}$ The present finding of higher rate of smokers may be explained by the increase of smoking habit particularly in younger individuals. The majority of the participants in our study presented significant psychological stress as one of the major reasons for smoking due to the daily life and education system. This finding is also parallel to the previous reports focusing on dental students from other countries such as Canada and New Zealand. ${ }^{18,19}$

It has been suggested that the rate of smoking increases with increasing school year. ${ }^{20}$ The present study focused on the first and fifth year students to find out whether an increase or decrease occurs in the smoking habits. Parallel to the previous reports, the present findings showed that the tobacco consumption increased similarly in both males and females with the increase in school year. ${ }^{21}$ Social factors such as the frequency of smokers among close friends and the personal need to be a member of a group can explain this increase. Moreover, the risk of environmental smoking seems to be rather high since the majority of non-smoker participants of the present study reported that they had at least one smoker friend. Furthermore, as expected, being an active smoker positively correlated with having a smoker friend and this is also in line with previous studies. ${ }^{22}$

Parental smoking plays an important role in early onset of smoking in adolescents. ${ }^{23,25}$ According to the present findings, most of the smokers and non-smokers reported to have non-smoker parents. There wasn't any significant difference between groups in parental smoking habits.

The rate of waterpipe smoking has been increasing in recent years particularly among the young population. ${ }^{26,27}$, Awan et al. assessed the prevalence of waterpipe smoking among healthcare university students in Saudi Arabia and $37 \%$ of the participants stated to have tried waterpipe, and the majority of these participants were current smokers $(62.1 \%, \mathrm{n}=123) .{ }^{28}$ In the same study, it was observed that dental students had a higher rate of waterpipe smoking $(45.5 \%)$ than the medical school students. The majority of the participants of another study stated a misbelief as such; smoking waterpipe was less harmful than smoking cigarette. ${ }^{28}$ The recent study of Hamadeh et al., which involved 335 medicine and nursing faculty students showed that hazards of waterpipe consumption was underestimated. It was emphasized that healthcare providers should be informed about the damages of waterpipe smoking. ${ }^{29}$ According to the present findings, smoking waterpipe was as common as smoking cigarette and $83.7 \%$ of the waterpipe smokers were not willing to quit waterpipe smoking. These findings clearly indicate that the harmful effects of waterpipes need to be explained better to the society.

Many active smokers misbelieve that their tobacco consumption is simply a bad habit and that they can quit whenever they want. They often do not fully understand or admit their addiction to nicotine or the strength of this addiction. Chinwong et al. estimated the nicotine dependence by using an objective scale called 'Fagerstrom Test for Nicotine Dependence' and nicotine addiction by means of subjective self-assessment questions. According to their findings, $71.7 \%$ of male and $88.4 \%$ of female participants were low nicotine dependants. ${ }^{30}$ The vast majority of those participants who have ever smoked have become an active smoker. This finding emphasizes the importance of efforts to keep non-smokers tobacco free. It was shown that there was a 
negative correlation between nicotine dependency level and smoking onset age. ${ }^{3}$ Comparatively fewer smokers admitted that they addicted to tobacco and this finding indicates a tendency to underestimate or ignore their state of smoking. The discrepancy between the rates of those smokers who wish to quit (55\%) and those who attempted during the previous six months (29\%) also supports this erroneous attitude.

Healthcare providers have the responsibility of being good role models not only for their patients but also for their families in terms of being tobacco free. Patients believe that dentists are qualified for cessation advice. ${ }^{31,32}$ Half of the patients willing to quit wish to have a cessation programme alongside with periodontal treatment. ${ }^{26}$ However, only $35 \%$ of periodontists spend more than 5 min of counselling although $99 \%$ ask smoking habits.

Questionnaire studies like this one has some limitations. First of all, there is a risk of false negatives

\section{References}

1. World Health Organization. WHO Report on The Global Tobacco Epidemic, Brazil 2008.

2. Wold B, Torsheim T, Currie C, Roberts C. National and school policies on restrictions of teacher smoking: a multilevel analysis of student exposure to teacher smoking in seven European countries. Health Educ Res. 2004; 19:217-226.

3. Mayhew KP, Flay BR, Mott JA. Stages in the development of adolescent smoking. Drug Alcohol Depend. 2000; 59:61-81

4. How Tobacco Smoke Causes Disease: The biology and behavioral basis for smoking-attributable disease: A report of the surgeon general. Centers for Disease Control and Prevention (US); National Center for Chronic Disease Prevention and Health Promotion (US); Office on Smoking and Health (US).

5. Johnson N. Tobacco use and oral cancer: a global perspective. J Dent Educ. 2001; 65:328-339.

6. Reibel J. Tobacco and oral diseases. Update on the evidence, with recommendations. Med Princ Pract. $2003 ; 12: 22-32$

7. Johnson GK, Slach N.A. Impact of tobacco use on periodontal status. J Dent Educ. 2001; 65:313-321. due to the social pressure or self-conflicts. Moreover, those who stated to be non-smokers may well be passive smokers making the findings even more critical. On the other hand, the present study gathered data from different regions of Turkey making a nationwide representation possible. Moreover, this survey has a participant population that is more heterogeneous in terms of socioeconomical level, parental education, life styles, etc. compared to data coming from one or two dental schools.

\section{Conclusion}

Within the limits of the present study, it can be concluded that the rate of tobacco smokers is rather high among dental school students in Turkey and this finding points out the need for developing more effective precautions against tobacco consumption. As dentists, we should be aware of the great power and opportunity to help our patients to quit! We should train our students to increase their skills and knowledge in smoking cessation counselling.

8. Khami MR, Murtomaa H, Razeghi S, Virtanen JI. Smoking and its determinants among Iranian dental students. Med Princ Pract. 2010; 19:390-394.

9. Komu P, Dimba EA, Macigo FG, Ogwell AE. Cigarette smoking and oral health among healthcare students. East Afr Med J. 2009; 86:178-182.

10. Smith DR, Leggat PA. An international review of tobacco smoking among medical student. J Postgrad Med. 2007;53;55-62.

11. Senol Y, Donmez L, Turkay M, Aktekin M. The incidence of smoking and risk factors for smoking initiation in medical faculty students: Cohort study. BMC Public Health 2006; 6:128.

12. Güleç M, Bakir B, Özer M. Association between cigarette smoking and depressive symptoms among military medical students in Turkey. Psychiatry Res. 2005; 134:281-286.

13. Barber M, Fairclough A. Verifiable CPD paper: A comparison of alcohol and drug use among dental undergraduates and a group of non-medical, professional undergraduates. $B r$ Dent J. 2006; 201:581-589.

14. Kara S, Yıldırım BF, Açıkalın C. Attitude to smoking and affecting factors: A study of first and last term students of medical and dentistry faculties. Smyrna Med J. 2011;16-21. 
15. Keshavarz H, Khami MR, Jafari A, Virtanen JI. Tobacco use among Iranian dental students: A national survey. East Mediterr Health J. 2013; 19:704-710.

16. Turkish Statistical Institute. Number: 13142 $31 / 08 / 2012$

17. Karadoğan D, Önal Ö, Kanbay Y. Prevalence and determinants of smoking status among university students: Artvin Çoruh University sample. PLoS One. 2018;13: e0200671.

18. Elani HW, Bedos C, Allison PJ. Sources of stress in Canadian dental students: a prospective mixed methods study. J Dent Educ. 2013; 77:1488-1497.

19. Harris RC, Millichamp CJ, Thomson WM. Stress and coping in fourth-year medical and dental students. N Z Dent J. 2015; 111:102-108.

20. Özcebe H. Youth and smoke. Ministery of Health Pub. 2008:731

21. Mercken L, Snijders TAB, Steglich C, de Vries H. Dynamics of adolescent friendship networks and smoking behavior: social network analyses in six European countries. Soc Sci Med. 2009; 69:15061514.

22. Martinelli E, Palmer RM. Smoking behaviour and attitudes to periodontal health and quit smoking in patients with periodontal disease. JClin Periodontol. 2008; 35:944-954.

23. Sargent JD, Tanski, S, Stoolmiller, M. Influence of motion picture rating on adolescent response to movie smoking. Pediatrics. 2012; 130:228-236.

24. Alomari Q, Barrieshi-Nusair K. Smoking prevalence and its effect on dental health attitudes and behavior among dental students. Med Princ Pract. 2006; 15:195-199.
25. Frech A. Healthy behaviour trajectories between adolescence and young adulthood. Adv Life Course Res. 2012; 17: 59-68.

26. Marshall L, Schooley M, Ryan H, Cox P, Easton A, Healton C, Jackson K, Davis KC, Homsi G. Centers for disease control and prevention. Youth tobacco surveillance - United States, 2001-2002. MMWR Surveill. 2006; 55:1-56.

27. Salameh P, Salame' J, Waked M, Barbour B, Zeidan $\mathrm{N}$, Baldi I. Risk perception, motives and behaviours in university students. Int J Adolesc. 2014; 3:279292.

28. Awan KH, Alrshedan A, Al Kahtani M, Patil S. Waterpipe smoking among health sciences university students: Knowledge, attitude and patterns of use. Saudi Dent J. 2016; 28:189-193.

29. Hamadeh RR, Ahmed J, Ghufran A, Sayed MA, Khladoon AR. Knowledge of health professional students on waterpipe tobacco smoking: curricula implications. BMC Medic Educ. 2018; 18:300

30. Chinwong D, Mookmanee N, Chongpornchai J, Chinwong S. A comparison of gender differences in smoking behaviours, intention to quit, and nicotine dependence among Thai university students. $J$ Addict. 2018; 8081670.

31. Ford PJ, Tran P, Cockburn N, Keen B, Kavanagh DJ, Gartner C. Survey of dental clinic patients: smoking and preferences for cessation support. Aust Dent J. 2016; 61:219-226.

32. Sood P, Narang R, Swathi V, Mittal L, Jha K, Gupta A. Dental patient's knowledge and perceptions about the effects of smoking and role of dentists in smoking cessation activities. Eur J Dent. 2014; $8: 216-223$ 